\title{
Hubungan Beban dengan Kemampuan Keluarga Merawat Activity Of Daily Living (ADL) Pasien Skizofrenia
}

\author{
Arina Addiba ${ }^{1}$, Zumrotul Choiriyyah $^{2}$, Liyanovitasari $^{3}$ \\ ${ }^{1,2,3}$ Program studi S1 Keperawatan, Universitas Ngudi Waluyo \\ Email: arinaaddiba63@gmail.com
}

\begin{abstract}
ABSTRAK
Keluarga merupakan caregiver utama bagi pasien skizofrenia. Lamanya perawatan yang dibutuhkan oleh pasien skizofrenia seringkali menyebabkan beban keluarga. Beban keluarga yang dirasakan keluarga dapat menurunkan kemampuan keluarga dalam merawat Activity of Daily Living (ADL) pasien. Tujuan penelitian ini adalah menganalisis hubungan beban keluarga dengan kemampuan keluarga dalam merawat ADL pasien skizofrenia. Desain penelitian deskriptif korelatif dengan pendekatan cross sectional. Populasi dalam penelitian ini adalah seluruh keluarga pasien skizofrenia dengan sampel penelitian berjumlah 94 responden dengan teknik purposive sampling. Pengumpulan data menggunakan kuesioner Zarith Burden Interview dengan Uji korelasi Kendal's Tau. Hasil penelitian menunjukkan 52,32\% responden mengalami beban ringan, dengan $72,34 \%$ responden memiliki kemampuan merawat ADL yang cukup mampu. Hasil uji statistik menunjukkan p-value sebesar 0,000 $(\alpha=0,001)$, maka dapat disimpulkan ada hubungan antara beban keluarga dengan kemampuan keluarga merawat Activity of Daily Living (ADL) pasien skizofrenia. Diharapkan pemberi pelayanan kesehatan dapat memberi terapi suportif pada keluarga untuk mengurangi beban keluarga dan meingkatkan kemampuan keluarga dalam merawat pasien skizofrenia
\end{abstract}

\section{Kata kunci : Beban Keluarga, Activity of Daily Living, Skizofenia}

\section{ABSTRACT}

Relationship between Load and Family Ability to Care for Activity Of Daily Living (ADL) in Schizophrenia Patients

Family burden that felt by family can decrease the family's ability to take care of patient's ADL. The aim of this study is to analyze the correlation between family burden and family's ability to take care of Activity Of Daily Living (ADL) of schizophrenia patients. The design descriptive correlation with cross sectional approach. The population of this research was the whole of the patient's family with the amount of samples were 94 respondents with purposive sampling. The data collection used questionnaire of The Zarith Burden Interview with Kendal's Tau test. The result of this reseach show that 52,32\% of the respondents have mild burden, and $72,34 \%$ of the repondent have enough ability to take care of skizofrenia's ADL. Statistical test result show p value 0,000 $(\alpha=0,001)$, it can be concluded that there is correlation between family burden and family's ability to take care Activity of Daily Living (ADL) of schizophrenia patients. Health care providers are expected to be able to provide supportive therapy for the patient's

Hubungan Beban dengan ... Arina Addiba, Zumrotul Choiriyyah, Liyanovitasari Journal of Holistics and Health Sciences Vol. 2, No. 2 September 2020 
family to reduce family burden and increase family's ability to take care of schizophrenia patients.

Key Words : Family Burden, Activity Of Daily Living, Schizophrenia.

\section{PENDAHULUAN}

Skizofrenia adalah salah satu gangguan jiwa berat yang dapat memengaruhi pikiran, perasaan, dan perilaku individu (Yudhantara \& Istiqomah, 2018). Berdasarkan data dari Riskesdas tahun 2018 prevalensi gangguan jiwa skizofrenia atau psikosis di Indonesia mengalami peningkatan sebanyak 5,3\% dari tahun 2013 sampai 2018, yang awalnya hanya sebanyak $1,7 \%$ meningkat menjadi $7 \%$ per mil.

Dampak skizofrenia pada pasien sendiri dapat menyebabkan menurunnya kualitas hidup pasien, perubahan proses berpikir yang memengaruhi bahasa, persepsi, dan kesadaran diri. Perubahan- perubahan tersebut menyebabkan kemunduran dalam menjalankan kegiatan seharihari yang dapat ditandai dengan hilangnya motivasi dan tanggung jawab. Selain itu, pasien cenderung apatis, menghindari kegiatan dan mengalami gangguan dalam penampilan. Perubahan proses pikir juga dapat menimbulkan penurunan kemampuan untuk melakukan aktivitas sehari-hari (Activity of Daily Living) seperti perawatan diri yang akan berdampak pada ketidakmampuan pasien untuk berfungsi secara optimal baik di rumah, sekolah, tempat kerja , dan lain-lain (Rini, 2016).

Activity of Daily Living (ADL) adalah kegiatan melakukan pekerjaan rutin sehari-hari. ADL merupakan aktivitas pokok bagi perawatan diri. Perawatan ADL yang dimaksud adalah perawatan diri yang meliputi : toileting, makan, berpakaian (berdandan), dan mandi. Kurangnya kemampuan pasien skizofrenia dalam melakukan ADL merupakan akibat dari penurunan kemampuan realitas pasien. Selain hal tersebut, penurunan kemampuan melakukan ADL pada pasien skizofrenia juga dapat disebabkan dari ketidakmampuan keluarga yang dapat dipengaruhi oleh stres ketika merawat pasien skizofrenia (Yulia, 2013). Fontaine

menjelaskan bahwa kemampuan keluarga dalam merawat anggota keluarganya ditentukan oleh kemampuan untuk memanajemen stres yang produktif. American Psychological Association (APA, 2015) melaporkan bahwa keluarga yang menjadi caregiver mengalami ketegangan peran sehingga memiliki tingkat depresi dan kecemasan yang cukup tinggi. Sementara pada lingkungan sosial dampak yang dialami keluarga yaitu pengasingan dari orang lain atau dikucilkan dari lingkungan sekitarnya.

Pada keluarga dengan gangguan jiwa, stressor yang dihadapi berbeda dengan keluarga dengan masalah kesehatan lain. Selain berkaitan dengan biaya yang dikeluarkan untuk perawatan, ketidakmampuan klien dalam memenuhi kebutuhan sehari-hari juga pada stigma masyarakat pada klien gangguan jiwa. Stressor yang dialami oleh keluarga dengan gangguan jiwa sering dikenal dengan beban keluarga (family burden) (Ngadiran, 2010). 
Beban keluarga adalah tingkat pengalaman yang tidak menyenangkan dalam keluarga sebagai efek dari kondisi anggota keluarganya. Kondisi ini dapat menyebabkan meningkatnya stres emosional dan ekonomi dari keluarga (Fontaine, 2009). Beban keluarga dibagi menjadi dua yaitu beban objektif yaitu beban dan hambatan yang dijumpai dalam kehidupan suatu keluarga yang berhubungan dengan pelaksanaan merawat salah satu keluarga yang menderita dan beban subyektif yang merupakan beban yang berupa distres emosional yang dialami anggota keluarga yang menderita (WHO, 2008).

Suhita (2016) dalam desesrtasinya menyebuikan bahwa keluarga yang merawat pasien skizofrenia mengalami kecemasan dan kebingungan dalam merawat anggota keluarga yang menderita skizofrenia. Sebagian keluarga yang mengasuh pasien skizofrenia adalah orang tua, yanglebih mengutamakan dan melindungi anggota keluarga yang sehat daripada anggota keluarga yang menderita skizofrenia, beberapa keluarga tidak siap untuk menjadi pengasuh untuk saudara dengan skizofrenia (Yang,dkk, 2017).

\section{METODE PENELITIAN}

Metode yang digunakan yaitu deskripsi korelatif dengan pendekatan cross sectional. Penelitian ini dilakukan pada tanggal 29 Februari 9 Maret 2020 di Poliklinik RSJ Prof. Dr. Soerojo Magelang. Populasi dalam penelitian ini sebanyak 1558 pasien dengan jumlah sampel 94 responden yang didapatakan melalui rumus Slovin dengan tingkat signifikansi 1\%. Teknik sampling yang digunakan yaitu purposive sampling.
Instrumen yang digunakan yaitu kuesioner beban The Zarith Burden Interview versi Bahasa Indonesia dan kuesioner kemampuan keluarga dalam merawat ADL pasien skizofrenia.

Analisis statistik yang digunakan adalah Uji Kendal's Tau untuk mengetahui seberapa erat hubungan variabel beban keluarga dengan kemampuan keluarga dalam merawat ADL pasien skizofrenia.

HASIL PENELITIAN

Tabel 1 Distribusi frekuensi responden berdasarkan jenis kelamin, usia pekerjaan, pendidikan terakhir, hubungan dengan pasien, lama pasien terdiagnosa dan lama merawat pasien.

\begin{tabular}{|c|c|c|}
\hline $\begin{array}{l}\text { Karakteristi } \\
\mathrm{k}\end{array}$ & $\begin{array}{l}\text { Frekuensi(f } \\
\text { ) }\end{array}$ & $\begin{array}{l}\text { Presentasi }(\% \\
)\end{array}$ \\
\hline \multicolumn{3}{|l|}{ Jenis } \\
\hline kelamin & 57 & $60,64 \%$ \\
\hline Perempuan & 37 & $39,36 \%$ \\
\hline \multicolumn{3}{|l|}{ Laki-laki } \\
\hline \multicolumn{3}{|l|}{ Agama } \\
\hline Islam & 90 & $95,74 \%$ \\
\hline Kristen & 4 & $4,26 \%$ \\
\hline Hindu & 0 & $0 \%$ \\
\hline Buddha & 0 & $0 \%$ \\
\hline \multicolumn{3}{|l|}{ Usia } \\
\hline$<30$ tahun & 10 & $10,64 \%$ \\
\hline 31-40 tahun & 24 & $25,53 \%$ \\
\hline $41-50$ tahun & 36 & $27,66 \%$ \\
\hline 51-60 tahun & 24 & $25,53 \%$ \\
\hline$>60$ tahun & 0 & $0 \%$ \\
\hline \multicolumn{3}{|l|}{ Pekerjaan } \\
\hline Tidak & 6 & $6,38 \%$ \\
\hline bekerja & 6 & $63,83 \%$ \\
\hline PNS & 28 & $29,79 \%$ \\
\hline Wiraswasta & 0 & $0 \%$ \\
\hline TNI/Polri & 54 & $57,45 \%$ \\
\hline \multicolumn{3}{|l|}{ Lain -lain } \\
\hline \multicolumn{3}{|l|}{$\begin{array}{l}\text { Pendidikan } \\
\text { terakhir }\end{array}$} \\
\hline Tidak & 0 & $0 \%$ \\
\hline sekolah & 19 & $20,21 \%$ \\
\hline SD & 15 & $15,96 \%$ \\
\hline SMP & 52 & $55,32 \%$ \\
\hline SMA & 8 & $8,51 \%$ \\
\hline \multicolumn{3}{|l|}{ PT } \\
\hline \multicolumn{3}{|l|}{$\begin{array}{l}\text { Hubungan } \\
\text { dengan }\end{array}$} \\
\hline pasien & '23 & $24,47 \%$ \\
\hline
\end{tabular}




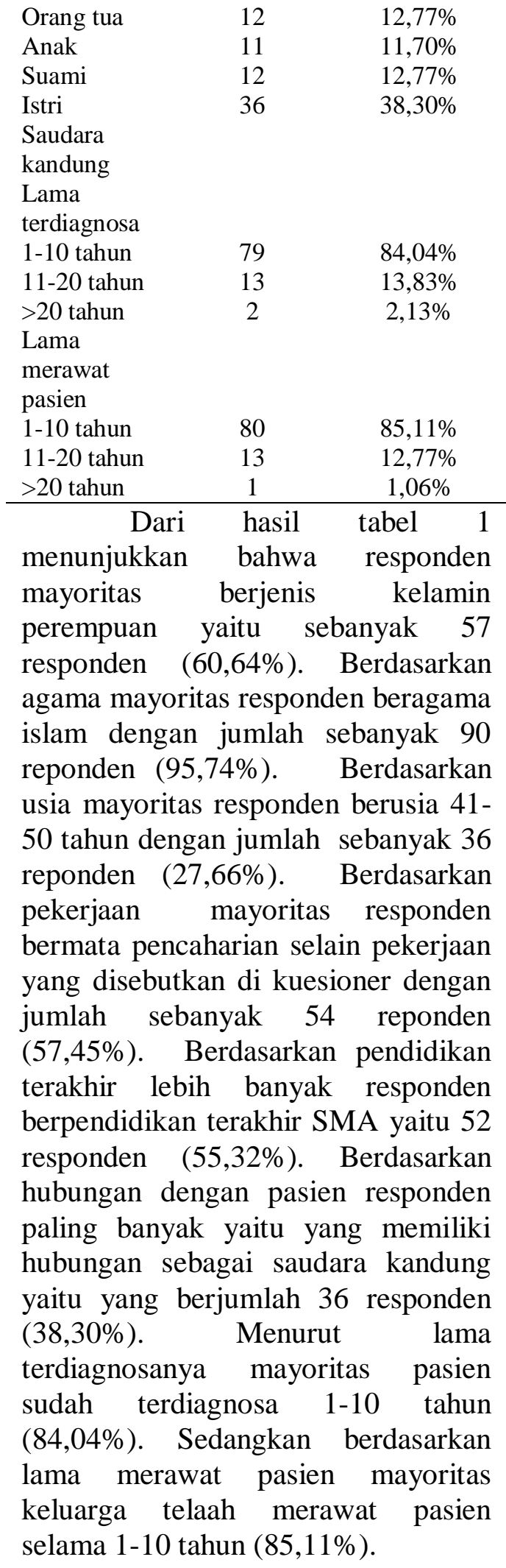

Tabel 2 Distribusi Frekuensi berdasarkan Beban Keluarga yang merawat pasien skizofrenia di poliklinik RSJ. Prof. Dr. Soerojo Magelang

\begin{tabular}{lcc}
\hline Kategori & $\begin{array}{c}\text { Frekuensi } \\
(\mathrm{f})\end{array}$ & $\begin{array}{c}\text { Presentase } \\
(\%)\end{array}$ \\
\hline Tidak ada & 21 & $22,34 \%$ \\
beban & & \\
Beban ringan & 52 & $55,32 \%$ \\
Beban sedang & 20 & $21,28 \%$ \\
Beban berat & 1 & $1,06 \%$ \\
\hline
\end{tabular}

\section{Berdasarkan tabel 2}

menunjukkan bahwa keluarga yang merawat pasien skizofrenia di poliklinik RSJ. Prof. Dr. Soerojo Magelang yang menjadi reponden mayoritas memiliki kategori beban ringan sebanyak 52 responden $(55,32 \%)$

Tabel 3 Distribusi Frekuensi berdasarkan kemampuan keluarga merawat ADL pasien skizofrenia di poliklinik RSJ. Prof. Dr. Soerojo Magelang

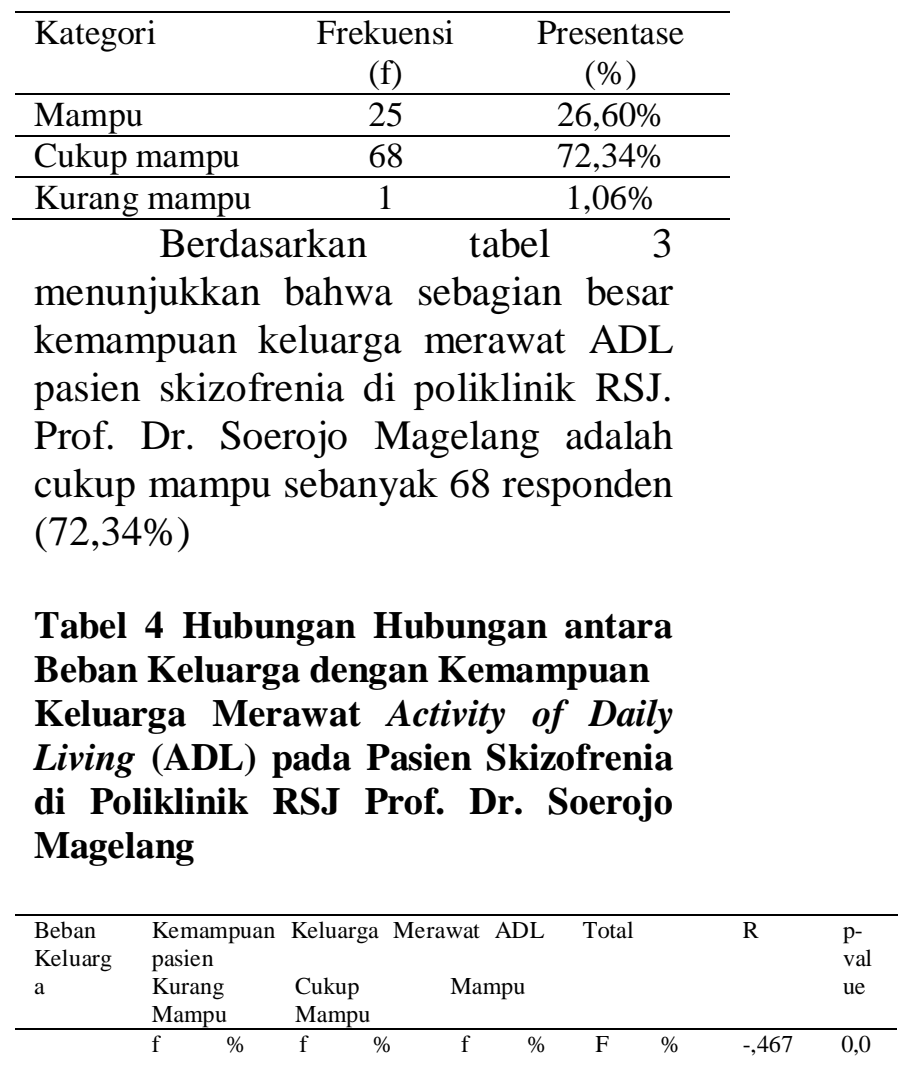




\begin{tabular}{|c|c|c|c|c|c|c|c|c|}
\hline $\begin{array}{l}\text { Tidak } \\
\text { ada } \\
\text { beban }\end{array}$ & 0 & 0 & 8 & 38,1 & 13 & $\begin{array}{l}61 \\
9 \\
0\end{array}$ & 21 & 100 \\
\hline $\begin{array}{l}\text { Beban } \\
\text { ringan }\end{array}$ & 0 & 0 & 40 & $\begin{array}{l}76,9 \\
2\end{array}$ & 12 & $\begin{array}{l}23 \\
, 0 \\
8\end{array}$ & 52 & 100 \\
\hline $\begin{array}{l}\text { Beban } \\
\text { sedang }\end{array}$ & 0 & 0 & 20 & 100 & 0 & 0 & 20 & 100 \\
\hline $\begin{array}{l}\text { Beban } \\
\text { berat }\end{array}$ & 1 & $\begin{array}{l}10 \\
0\end{array}$ & 0 & 0 & 0 & 0 & 1 & 100 \\
\hline Jumlah & 1,1 & $\begin{array}{l}10 \\
6\end{array}$ & $\begin{array}{l}72, \\
3\end{array}$ & $\begin{array}{l}228, \\
74\end{array}$ & $\begin{array}{l}26 \\
, 6\end{array}$ & $\begin{array}{l}90 \\
, 4\end{array}$ & 94 & 100 \\
\hline
\end{tabular}

Hasil uji korelasi Kendal's Tau diperoleh p-value sebesar $0,000 \quad(\alpha=0,001)$ maka didapat disimpulkan ada hubungan yang bermakna antara beban keluarga dengan kemampuan keluarga merawat ADL pasien skizofrenia di poliklinik RSJ. Prof. Dr. Soerojo Magelang.

\section{PEMBAHASAN}

\section{Gambaran Beban Keluarga} yang Merawat ADL Pasien Skizofrenia di Poliklinik RSJ Prof. Dr. Soerojo Magelang

Hasil penelitian pada tabel

2 menunjukkan bahwa mayoritas keluarga yang mengantar pasien skizofrenia untuk berobat di poliklinik RSJ Prof. Dr. Soerojo Magelang yang menjadi responden berada pada kategori beban ringan dalam merawat pasien skizofrenia dengan jumlah sebanyak 52 responden ( 55,3\%).

Berdasarkan data demografis didapatkan data bahwa mayoritas responden yang mengalami beban ringan yaitu responden yang berjenis kelamin perempuan berjumlah 34 responden $(36,2 \%)$, responden perempuan dengan beban sedang berjumlah 9 responden $(9,6 \%)$, pada responden laki-laki didapatkan reponden dengan beban ringan berjumlah 18 responden $(19,1 \%), 11$ responden dengan beban sedang $(11,1 \%)$, dan 1 responden dengan beban berat $(1,1 \%)$.
00 Hal ini tidak sejalan dengan penelitian yang dilakukan Schneider, M., Steele, R., Cadell, S., \& Hemsworth (2010) yang menyatakan bahwa perempuan memiliki skor yang lebih tinggi dalam perawatan, depresi, dan beban daripada laki-laki. Hal ini disebabkan oleh faktor peran sosial dan faktor hormonal.

Berdasarkan data demografis didapatkan data bahwa mayoritas responden yang mengalami beban ringan berada pada rentang usia 41-50 tahun yaitu berjumlah sebanyak 26 reponden $(50 \%)$, sedangkan responden yang memiliki beban berat yaitu berumur $<30$ tahun.

Hasil dari penelitian ini mayoritas responden yang memiliki beban ringan yaitu responden dengan tingkat pendidikan SMA sejumlah 27 responden $(28,7 \%)$, tidak ada beban berjumlah 12 responden (12,8\%), beban sedang $(12,8 \%)$ dan beban berat 1 responden $(1,1 \%)$.

Hal ini sejalan dengan penelitian Juvang, L., Lambert C. E., \& Lambert (2007) yang menyatakan bahwa semakain tinggi tingkat pendidikan, maka semakin tinggi gaji yang akan diterima. Tingginya gaji akan mengurangi masalah finansial yang berhubungan dengan penyediaan perawatan untuk anggota keluarga yang sakit. Tingkat pendidikan yang dimiliki caregiver juga cenderung memiliki pengetahuan untuk mengatasi kejadian yang dapat menyebabkan stres.

Pada hasil penelitian ini didapatkan bahwa mayoritas responden memiliki beban ringan yaitu yang memiliki pekerjaan lainlain berjumlah 33 responden $(35,1 \%)$ , sedangkan pada beban berat ditemukan pada responden yang 
bekerja sebagai wiraswasta berjumlah 1 responden $(1,1 \%)$.

Gusdiansyah (2018) keluarga yang memiliki pendapatan rendah dengan skizofrenia menyatakan merasa terbebani karena keluarga selalu memikirkan biaya untuk pengobatan atau merawat anggota keluarga yang mengalami gangguan jiwa. Kondisi ini dapat menyebabkan peningkatan stres emosional, beban mental dan fisik dalam menghadapi perilaku pasien.

Pada penelitian ini mayoritas responden yang memiliki beban ringan yaitu responden yang telah merawat pasien yang telah terdiagnosa dan telah dirawat selama kurun waktu 1-10 tahun. Pada responden dengan pasien lama yang telah terdiagnosa dalam rentang waktu 1-10 tahun terdiri dari 45 responden $(47,9 \%)$ dengan beban ringan, 18 responden $(19,1 \%)$ beban sedang, dan 1 responden $(1,1)$ dengan beban berat. Pada responden dengan lama perawatan 1-10 tahun terdiri dari 46 responden $(48,9 \%)$ dengan beban ringan, 18 responden $(19,1 \%)$ beban sedang, dan 1 responden $(1,1)$ dengan beban berat.

Sejalan dengan penelitian Mirza, Raihan, dan Hendra (2015) yang menyatakan bahwa tidak ada hubungan antara lama merawat dengan beban keluarga, keluarga pasien tidak mengalami stres/normal meskipun membutuhkan waktu yang lama untuk merawat pasien. Berdasarkan teori "The Five Stages of Grief" yang menyatakan keluarga telah berada pada tahap acceptance (penerimaan) sehingga mereka cenderung pasrah dan mampu beradaptasi dengan keadaan pasien yang menyebabkan keluarga sebagai caregiver berada pada kondisi normal/tidak stres dalam merawat pasien meskipun perawatan pasien membutuhkan waktu yang lama.

\section{Gambaran Kemampuan \\ Keluarga yang Merawat ADL Pasien Skizofrenia di Poliklinik RSJ Prof. Dr. Soerojo Magelang}

Berdasarkan tabel 3 mayoritas responden berada pada kategori kemampuan yang cukup mampu yaitu sebanyak 68 responden (72,34\%), 25 responden $(26,60 \%)$ dalam kategori mampu, dan pada kategori tidak mampu sebanyak 1 responden $(1,06 \%)$.

Hasil penelitian menunjukkan bahwa mayoritas responden memiliki kemampuan merawat ADL yang cukup mampu yaitu sebanyak 37 responden $(39,4 \%)$ mempunyai pendidikan terakhir SMA, sedangkan responden yang memiliki tingkat kemampuan mampu dalam merawat ADL pasien skizofrenia sebanyak 14 responden $(14,9 \%)$

Rafiyah (2011) menyatakan semakin tinggi pendidikan yang dimiliki maka akan memberikan pengetahuan yang lebih besar sehingga menghasilkan kebiasaan mempertahankan kesehatan yang lebih baik.

Menurut penelitian Shu, Yi. Chiao (2008) keluarga adalah orang paling penting untuk orang skizofrenia. $60-85 \%$ dari orang-orang cacat atau gangguan mental, kebutuhan self care dibantu oleh keluarga. Hasil penelitian Arsova (2014) menunjukkan bahwa pasien dengan skizofrenia memiliki masalah berat terhadap pemenuhan self care mereka.

Penelitian yang dilakukan peneliti di RSJ Prof. Dr. Soeroyo menunjukkan bahwa kememampuan keluarga mayoritas memiliki kemampuan yang cukup baik dalam 
memberikan perawatan ADL meskipun mereka memeliki beban ringan, hal tersebut dikarenakan keluarga membiarkan pasien beraktivitas sendiri karena pasien dirasa sudah mampu untuk melakukan ADL nya secara mandiri sehingga keluarga tidak terlalu memerhatikan ADL pasien dan karena harus bekerja maka waktu yang dihabiskan untuk merawat pasien juga lebih sedikit.

3. Hubungan antara Beban Keluarga dengan Kemampuan Keluarga Merawat Activity of Daily Living (ADL) Pasien Skizofrenia di Poliklinik RSJ Prof. Dr. Soerojo Magelang

Berdasarkan tabel 4 menunjukkan bahwa mayoritas responden memiliki kategori beban ringan dalam merawat pasien skizofrenia dengan kategori kemampuan merawat ADL mampu yaitu sebanyak 12 responden $(12,8 \%)$.

Hasil uji korelasi Kendal's Tau diperoleh p-value sebesar $0,000 \quad(\alpha=0,001)$, maka dapat disimpulkan ada hubungan yang bermakna antara beban keluarga dengan kemampuan keluarga merawat Activity of Daily Living (ADL) pasien skizofrenia di poliklinik RSJ Prof. Dr. Soerojo Magelang.

Hasil uji statistik dengan menggunakan uji korelasi Kendal's Tau diperoleh nilai $r$ sebesar $-0,467$. Hasil uji statistik ini menunjukkan adanya hubungan negatif antara antara beban keluarga dengan kemampuan keluarga merawat Activity of Daily Living (ADL) pasien skizofrenia di poliklinik RSJ Prof. Dr. Soerojo Magelang, artinya artinya jika keluarga memiliki beban yang ringan maka keluarga akan semakin mampu dalam merawat Activity of Daily Living (ADL) pasien skizofrenia.

Sejalan dengan penelitian yang dilakukan oleh Yulia, (2013) menjelaskan bahwa terdapat hubungan yang signifikan dengan arah negatif antara beban keluarga dengan kemampuan keluarga merawat ADL pada pasien skizofrenia.

Hasil uji statistik pada penelitian ini menunjukkan bahwa keeratan hubungan cukup kuat, dapat diartikan bahwa mayoritas responden yang memiliki beban ringan adalah responden yang memiliki kemampuan yang mampu dalam merawat ADL pasien skizofrenia.

\section{SIMPULAN}

1. Beban keluarga sebagian besar memiliki beban ringan sebanyak 52 responden $(52,32 \%)$,

2. Kemampuan keluarga merawat Activity of Daily Living (ADL) pasien skizofrenia sebagian besar dalam kategori cukup mampu yaitu sebanyak 68 responden $(72,34 \%)$,

3. Hasil uji kendal tau 0,000 yakni terdapat hubungan antara beban keluarga dengan kemampuan keluarga merawat Activity of Daily Living (ADL) pasien skizofrenia di poliklinik RSJ Prof. Dr. Soerojo Magelang.

\section{SARAN}

a. Bagi Keluarga

Diharapkan keluarga mengajak, membimbing, dan mendampingi pasien untuk melaksanakan kegiatan seharihari dan melakukan kegiatan sosialisasi dengan tujuan menciptakan kemandirian bagi 
penderita dalam menjalankan kegiatan sehari-hari dan sosialisasi.

\section{b. Bagi Peneliti Selanjutnya}

Diharapkan untuk peneliti selanjutnya dapat meneliti lebih lanjut mengenai efektifitas terapi psikoedukasi pada keluarga skizofrenia untuk meningkatkan kemampuan caregiver dalam memberikan perawatan pada pasien skizofrenia.

\section{UCAPAN TERIMA KASIH}

Kami ucapkan terima kasih kepada RSJ Prof. Dr. Soerojo Magelang atas kelancaran penelitian ini

\section{DAFTAR PUSTAKA}

Arsova, S. B. B. (2014). Patients With Schizophrenia And Self Care. Journal of Medical Sciences, 11(17), 221-229.

Association, A. P. (2015). Family Caregiving. Retrieved From Http://Www.Apa.Or

Fontaine, K. L. (2009). Mental Health Nursing. New Jersey: Pearson Education Inc.

Gusdiansyah, E. (2018). Hubungan Dukungan Dan Beban Keluarga Dengan Tingkatan Skizofrenia. Jurnal Kesehatan Lentera Aisyah, 1(1), 41-54.

Juvang, L., Lambert C. E., \& Lambert, V. A. (2007). Predictors of Family Caregiver"S Burden And Quality Of Life When Providing Care For A Family Member With Schizophrenia In The People"S Republic of China. Nursing And Health Sciences, 192-198.
Mirza, R. K. (2015). Hubungan Lamanya Perawatan Pasien Skizofrenia Dengan Distress Keluarga. Jurnal Kedokteran Syiah Kuala, 15, 179-189.

Rafiyah, I., Kp, S., Prof, A., \& Sutharangsee, W. (2011). Review: Burden On Family Caregivers Caring For Patients With Schizophrenia And Its Related Factors, (January), 2941.

Rini, A. S. (2016). Activity Of Daily Living ( Adl ) Untuk Meningkatkan Kemampuan Rawat Diri. Dinamika Penelitian, 16, 207-220.

Schneider, M., Steele, R., Cadell, S., \& Hemsworth, D. (2010). Differences On Psychosocial Outcomes Between Male And Female Caregivers of Children With Life-Limiting Illness. Journal Of Pediatric Nursing, 114.

Shu, Yi. Chiao, L. (2008). Exploring The Burden Of The Primary Family Caregiver of Schizophrenia Patients In Taiwan. Psyciatrhy And Clinical Neurosciences.

Suhita. (2016). Model Adaptasi Care Giver Dalam Merawat Anggota Keluarga Dengan Skizofrenia Di Kota Kediri. Universitas Airlangga. Surabaya.

Yang, Hseih, Lee.L, C. S. . (2017). Experiences Of Caring For A Sibling With Schizophrenia In A Chinese Context: A Neglected Issue. International Journal Of 
Mental Health Nursing, 409417.

Yudhantara, D. S. Dan R. I. (2018). Sinopsis Skizofrenia. Malang: UB Press.

Yulia, I. Dan S. S. (2013). Hubungan
Antara Beban Keluarga Dengan Kemampuan Keluarga Merawat Pasien Perilaku Kekerasan Di Poliklinik Rumah Sakit Marzoeki Mahdi Bogor (Vol. 1). 